\title{
Aligning ENERGY DEVELOPMENT WITH THE InTERests of Aboriginal PeOples in Canada
}

\author{
WILLIAM M. LAURIN ${ }^{*}$ AND JOANN P. JAMIESON ${ }^{* *}$
}

\begin{abstract}
Canada's economic future is dependent upon energy and natural resource development, and has therefore become inextricably linked to the rights and interests of Canada's Aboriginal peoples. These rights and interests include the desire to continue with their traditional ways of livelihood, to protect their many cultures and the environment, the need to foster healthy and thriving communities, and the opportunity to participate in and benefit from development on their traditional lands. In Canada, the rights of Aboriginal people are constitutionally protected. However, despite considerable advancements in domestic law on consultation and accommodation, growing unrest and dissatisfaction among Canada's Aboriginal peoples prevails.
\end{abstract}

Significant progress in international human rights law and international norms lend support to Indigenous aspirations and are creating pressure on energy and natural resource developers to embrace change and move beyond the consultation requirements under domestic law to obtaining the consent of Aboriginal communities to development on their traditional lands. This article posits that the willingness of Aboriginal communities to constructively engage with industry and consent to natural resource and energy development on their traditional lands can be facilitated by aligning the interests of the affected Aboriginal communities with those of project proponents through the proactive creation of thoughtful and innovative commercial relationships. These relationships can be structured to create value for the proponent while providing meaningful economic participation for the affected Aboriginal community by utilizing a combination of passive resource revenues, employment and procurement opportunities and direct equity participation in the development.

\section{TABLE OF CONTENTS}

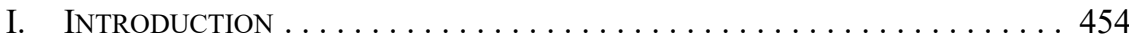

II. Why Canada NeEdS to Move Forward . . . . . . . . . . . . 456

A. The Rights of Canada's Aboriginal Peoples . . . . . . . . . . 456

B. The Law of Consultation and AcCommodation . . . . . . . . 457

C. WHY CANADA'S APPROACH INCREASES RISK TO ENERGY DEVELOPERS . . . . . . . . . . . . . . . . . . . . 459

III. RESPECTING TRADITIONAL LANDS FROM A HuMAN Rights PERSPECTIVE . . . . . . . . . . . . . . . . . . 460

A. THE UNITED NATIONS DECLARATION ON THE RightS OF INDIGENOUS PEOPLES . . . . . . . . . . . . 460

B. The Principle of Free, Prior, ANd Informed Consent . . . . . 461

C. CANAdA's Qualified ACCEPTANCE OF THE UN DECLARATION . . . . . . . . . . . . . . . . . 462

D. Corporate Initiatives to Respect Human Rights . . . . . . . 464

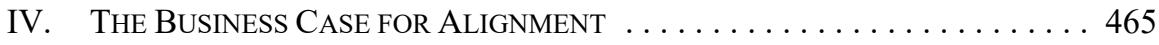

A. Impact of Above Ground Risk on Market VAlue . . . . . . . 466

** Vice-President and General Counsel, Native American Resource Partners.

Partner, Lawson Lundell LLP. The authors would like to acknowledge and thank Nigel Bankes, Professor of Law and Chair of Natural Resources Law at the University of Calgary for his time and thoughtful comments in preparing this article. 
B. Capital Provider Requirements $\ldots \ldots \ldots \ldots \ldots \ldots \ldots \ldots$

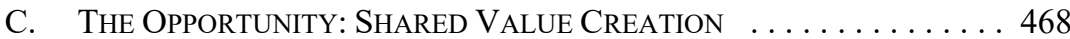

V. STRUCTURING COMMERCIAL RELATIONSHIPS

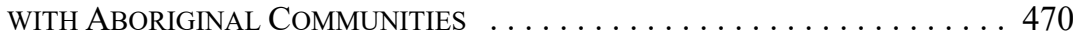

A. Unique Legal, Historical, and Cultural Context . . . . . 470

B. GOVERNANCE, LEADERSHIP, AND BUILDING COMMUNITY SUPPORT . . . . . . . . . . . 471

C. Structuring the Aboriginal Commercial Interest . . . . . . . 473

D. Structuring Aboriginal Equity PARTICIPATION . . . . . . . . . . . 474

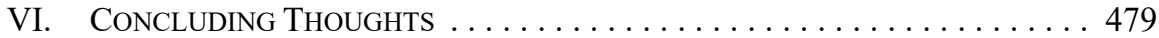

\section{INTRODUCTION}

Canada's economic future is dependent upon natural resource and energy development and has therefore become inextricably linked to the rights, interests, and influence of Canada's Aboriginal peoples where these developments are located on their traditional lands and territories. ${ }^{1}$ These rights and interests include the right to continue their traditional livelihoods, the desire to protect their many distinct cultures and the environment, the need to foster healthy and thriving communities, and the opportunity to participate in and benefit from development on their traditional lands. Canada's Aboriginal peoples are also actively pursuing self-determination and a sustainable future. ${ }^{2}$

In Canada, the rights of Aboriginal peoples are constitutionally protected. Notably, the Crown is under a good faith duty to consult with and possibly accommodate the rights of Aboriginal peoples when it is contemplating action that may adversely affect those rights. Authorizing energy development on traditional lands often gives rise to the duty and government bodies and regulatory authorities have been striving in earnest to ensure the duty is satisfied. However, despite considerable advances in the domestic law in this area, there is growing unrest and dissatisfaction among Canada's Aboriginal communities with the current approach. The impact to energy developers is readily apparent and evidenced by the increased legal, regulatory, financial, and reputational risks associated with permitting

1 In this article, the term "energy development" includes energy and natural resource developments and the infrastructure associated with those developments. "Developer" includes the proponents, owners, and operators of those energy developments. The term "Aboriginal peoples" is used as an equivalent to the term "Aboriginal Peoples of Canada" in Part I of the Constitution Act, 1982, being Schedule B to the Canada Act 1982 (UK), 1982, c 11 and includes the First Nations, the Métis, and the Inuit peoples of Canada, with the term "First Nations" used as an equivalent to the term "bands" under the Indian Act, RSC 1985, c I-5. While this article refers specifically to First Nations, the principles in general apply equally to Canada's Métis and Inuit communities. "Traditional lands and territories" includes those lands, territories, and resources traditionally or currently used or occupied by Aboriginal peoples, including where appropriate their reserve or settlement lands.

The Government of Canada recognizes the inherent right of self-government as an existing Aboriginal right under section 35 of the Constitution Act, 1982, supra note 2. In 1995, Canada launched a new process, The Inherent Right to Self-Government Policy. Since the introduction of that policy, there have been at least 21 self-government agreements concluded, many of which are part of the larger modern land claim settlement agreements. See Aboriginal Affairs and Northern Development Canada, "The Government of Canada's Approach to Implementation of the Inherent Right and the Negotiation of Aboriginal Self-Government," online: <www.aadnc-aandc.gc.ca/eng/1100100031843/1100100031844>. 
delays, operational disruptions, protests, and negative media attention, also known as "above ground risks."3

Canada's Aboriginal peoples are also part of a rapidly growing global population of Indigenous peoples. ${ }^{4}$ In the international arena, important developments are taking place in respect of Indigenous human rights which will inevitably influence and shape how the rights and interests of Canada's Aboriginal peoples are to be treated. Notably, the United Nations Declaration of the Rights of Indigenous People, ${ }^{5}$ developed in response to substantial pressure by the international human rights community, includes the principle of free, prior and informed consent which, inter alia, recognizes an inherent right of Indigenous peoples to benefit from development on their traditional lands.

While the emerging international norms aimed at protecting the human rights of Indigenous peoples are not expressly incorporated into the domestic law of Canada, they are beginning to influence and shape the expectations of affected Aboriginal communities and the approach they take with energy developers. These international developments are also beginning to impact the practical approaches used by energy developers to advance projects, and to provide support to the business case for finding a different approach to Aboriginal engagement.

What then is the common path forward for Canada's energy developers and affected Aboriginal communities? This article posits that in order for an energy development to successfully proceed in Canada within realistic and predictable timeframes, and continue to operate with minimal interruption from Aboriginal above ground risk over the long-term, proponents must first create a willingness on the part of affected Aboriginal communities to

In this article, the term "above ground risk" includes the legal, regulatory, financial and reputational nontechnical risks for energy developments associated with permitting delays, operational disruptions, protests, and negative media attention. Recent examples of Canadian developments subject to Aboriginal above ground risk include: The Canadian Press, "Alberta oilsands facing Aboriginal legal onslaught in 2014," CBC News (2 January 2014), online: <www.cbc.ca/news/politics/alberta-oilsands-facingaboriginal-legal-onslaught-in-2014-1.2481825> (various Athabasca Oil Sands projects); Mike Laanela, "Northern Gateway pipeline: First Nations outline constitutional challenges," CBC News (14 July 2014), online: <www.cbc.ca/news/canada/british-columbia/northern-gateway-pipeline-first-nations-outlineconstitutional-challenges-1.2706376> (Enbridge's Northern Gateway Pipeline Project); Obert Madondo, "First Nations: NEB Review of Kinder Morgan pipeline "fatally flawed," The Canadian Progessive (1 December 2014), online: <www.canadianprogressiveworld.com/2014/12/01/first-nations-neb-reviewkinder-morgan-pipeline-fatally-flawed/> (Kinder Morgan's Proposed Expansion of Trans Mountain Pipeline).

In this article, the term "Indigenous peoples" is used with reference to the modern understanding endorsed by the United Nations, and includes the following characteristics:

- Self-identification as indigenous peoples at the individual level and accepted by the community as their member

- Historical continuity with pre-colonial and/or pre-settler societies

- Strong link to territories and surrounding natural resources

- Distinct social, economic or political systems

- Distinct language, culture and beliefs

- Form non-dominant groups of society

- Resolve to maintain and reproduce their ancestral environments and systems as distinctive peoples and communities.

UNESC, Permanent Forum on Indigenous Issues, Indigenous Peoples, Indigenous Voices: Factsheet, 5th Sess, online: <www.un.org/esa/socdev/unpfii/documents/5session_factsheet1.pdf >.

United Nations Declaration on the Rights of Indigenous Peoples, GA Res 61/295, UNGAOR, 61st Sess, Supp No 49, UN Doc A/Res/61/295 (2007), online: <www.un.org/esa/socdev/unpfii/documents/ DRIPS en.pdf $>$ [UN Declaration]. In this article, the term "informed consent" refers to the doctrine of free, prior, and informed consent as contemplated in the specific context of Article 32 of the $U N$ Declaration. 
constructively engage with industry. The willingness of affected Aboriginal communities to constructively engage with energy developers, and ultimately provide their informed consent and social license, can be facilitated by aligning the interests of affected Aboriginal communities with those of the developer through the creation of thoughtful and innovative commercial relationships that benefit both the energy developer and the affected Aboriginal community.

\section{Why Canada NeEdS To Move ForWARD}

This section provides a brief overview of the Canadian law of consultation and accommodation in the context of illustrating why the current approach often leads to increased Aboriginal above ground risk for energy developers.

\section{A. The Rights of Canada's Aboriginal Peoples}

In Canada, Aboriginal and treaty rights are protected by section 35 of the Constitution Act, 1982:

(1) The existing Aboriginal and treaty rights of the Aboriginal peoples of Canada are hereby recognized and affirmed.

(2) In this Act, "Aboriginal peoples of Canada" includes the Indian, Inuit and Métis peoples of Canada. ${ }^{6}$

Aboriginal rights are those rights held by Aboriginal peoples due to their ancestors' longstanding use of lands prior to European contact and are designed to protect an activity or site which has an "element of a practice, custom or tradition integral to the distinctive culture of the Aboriginal group claiming the rights." In 1973, the Supreme Court of Canada ruled that Aboriginal rights survived European settlement and remain valid to the present day unless legally extinguished by treaty or otherwise. ${ }^{8}$

Aboriginal title is the highest form of Aboriginal right and "confers ownership rights similar to those associated with fee simple, including: the right to decide how the land will be used; the right of enjoyment and occupancy of the land; the right to possess the land; ... and the right to pro-actively use and manage the land." "Most importantly, the right to control access to the land "means that governments and others seeking to use the land must obtain the consent of the Aboriginal title holders." informed consent to the use, the government's only recourse is to establish that the proposed incursion on the land is justified.

Treaty rights arise from treaties. Treaties are unique legal instruments entered into between Aboriginal peoples and the Crown, and represent an exchange of solemn promises.

Supra note 1, s 35.

$R v$ Van der Peet, [1996] 2 SCR 507 at para 46. Examples of Aboriginal rights include, inter alia, fishing for food and ceremonial purposes, hunting, trapping, site-specific ceremonial rights, gathering sites, preservation of burial grounds, medicinal plant sites, berry picking, and logging for domestic purposes. Calder v British Columbia (AG), [1973] SCR 313.

Tsilhqot'in Nation v British Columbia, 2014 SCC 44, [2014] 2 SCR 257 at para 73 [Tsilhqot'in]. Ibid at para 76. 
There are two general categories of treaties: (1) the historical treaties (early 1700s to 1923), and (2) the modern land claim agreements (starting in 1973). The historical treaties include both the peace and friendship treaties and the "land cession" treaties. ${ }^{11}$ In general, the land cession treaties are viewed as a surrender of Aboriginal rights and title over a larger area in exchange for a defined set of treaty rights, some of which include quasi-exclusive rights to one or more smaller areas of land. Historical treaty rights may also include lump sum payments, annuities, reservations of land, the right to hunt and fish on unoccupied Crown land, rights to education, agricultural implements, health care, and some monies and tax allowances.

The passing of the Indian Act in 1876 brought greater authority to the Department of Indian Affairs to intervene in a variety of issues affecting First Nations people including membership, the management of Indian reserve lands, resources and moneys, access control and the promotion of "civilization." 12 Today, while reserve lands remain federal lands held for the benefit of a First Nation under the Indian Act, the elected leadership of the First Nation (typically its Chief and Council) generally has the right to provide the informed consent of the First Nation to energy development on reserve lands. ${ }^{13}$

Modern treaty rights arising out of comprehensive land claim settlement agreements are significantly broader and may include lands in fee simple, mineral rights, consultation and benefit rights, rights of self-government, and the right to manage, land, water, and wildlife. ${ }^{14}$ Each treaty is unique and must be carefully examined in order to understand the scope of the rights exchanged.

\section{B. The Law OF Consultation ANd ACCOMmodation}

In a series of decisions over the past decade, the Supreme Court of Canada has articulated that the Crown is obligated to consult with and possibly accommodate the rights of Aboriginal peoples when the Crown has knowledge, real or constructive, of those rights and

11 See Indian and Nothern Affairs Canada, A History of Treaty-Making in Canada (Ottawa: INAC, April 2010), online: Aboriginal Affairs and Northern Development Canada $<$ https://www.aadnc-aandc.gc.ca/ eng/1314977704533/1314977734895>. Starting in the early 1700 s, the British Crown entered into treaties to encourage peaceful relations between First Nations and non-Aboriginal people. The Treaty of Albany was signed in 1701 in Montreal between France, its Aboriginal allies, and the Iroquois to end the disruption of the fur trade. In the Maritimes, the Peace and Friendship Treaties were signed with Mi'kmaq, Maliseet, and Passamaquoddy First Nations. The Peace and Friendship Treaties did not include land cessation clauses (ibid at 3-4). The land surrender treaties include the Upper Canada Land Surrenders, the Williams Treaties, the Robinson Treaties, the Douglas Treaties (Vancouver Island) and the 11 Numbered Treaties (ibid at 6-8).

Ibid at 8 .

See the Indian Oil and Gas Act, RSC 1985, c I-7; Indian Oil and Gas Regulations, 1995, SOR/94-753. Indian Oil and Gas Canada may issue exploratory licences (ibid, s 6), and permits and leases or an option to acquire a permit or lease, in respect of oil and gas rights underlying Indian lands (ibid, s 10) with the approval of the band council.

Comprehensive land claims generally arise in areas of Canada where Aboriginal land rights have not been addressed by treaty or through other legal means. These treaties are implemented through legislation. See Aboriginal Affairs and Northern Development Canada, "Comprehensive Claims," online: < https://www.aadnc-aandc.gc.ca/eng/1100100030577/1100100030578>. See Aboriginal Affairs and Northern Development, "Fact Sheet: Implementation of Final Agreements," online: <https://www. aadnc-aandc.gc.ca/eng/1100100030580/1100100030581>(“"[s]ince 1973, 24 comprehensive land claims agreements covering over 40 percent of Canada's land mass have been ratified and brought into effect, 18 of which include self-government provisions. An additional three stand-alone self-government agreements are also in effect"). 
contemplates conduct that may adversely affect those rights. ${ }^{15}$ The source of the duty to consult is the honour of the Crown which gives rise to different duties in different circumstances. The scope of the duty to consult is to be determined on a spectrum which is based on an assessment of the asserted right and the seriousness of the potential impact on it, and will vary with the circumstances, from mere notice to "deep consultation."16

In order to satisfy its duty to consult, the Crown must act in good faith with the intention of substantially addressing the concerns raised. The Crown is not under a duty to reach an agreement; rather the obligation is to conduct a meaningful process. Aboriginal peoples, in turn, must participate in consultation in good faith. Ultimately, the controlling question is: "[w] hat is required to maintain the honour of the Crown and to effect reconciliation between the Crown and the Aboriginal peoples with respect to the interests at stake?"17

The Crown's duty to consult arises in the context of energy development when a proponent seeks land tenure, or environmental and regulatory approval for a proposed energy development. ${ }^{18}$ The possibility of the Crown not adequately fulfilling its duty to consult represents a significant source of legal and regulatory above ground risk for energy developers as permits and approvals are subject to delay and potential invalidation. Additionally, the inevitable delays, expense and possible reputational damage associated with legal and regulatory challenges further increase these risks.

To date, energy developers have generally managed these legal and regulatory risks through the conduct of good consultation practices and by entering into impact benefit agreements with potentially affected Aboriginal communities. ${ }^{19}$ Impact benefit agreements typically contain provisions on how the parties will work together and avoid or mitigate the identified impacts. Where the impacts are substantial, these agreements include various benefits to the affected Aboriginal community to offset the impacts. The benefits include education and training, capacity building, community investment funding, training and employment provisions, business opportunities, and in some cases, revenue sharing or participation rights. ${ }^{20}$ In exchange, the energy developer is granted some legal certainty with respect to its project, often in the form of a withdrawal of a regulatory intervention or a covenant not to oppose operations or commence future legal challenges. ${ }^{21}$ However, despite

Haida Nation v British Columbia (Minister of Forests), 2004 SCC 73, [2004] 3 SCR 511 [Haida].

Ibid at para 44 .

Ibid at para 45 .

Notably, the Crown is entitled to delegate procedural aspects of the duty to a proponent, however, ultimate satisfaction of the duty remains with the Crown. This is the case in Alberta, where the government of Alberta may delegate the procedural aspects of the duty to the proponent: see Alberta Aboriginal Relations, The Government of Alberta's Guidelines on Consultation with First Nations on Land and Natural Resource Management (Edmonton: AR, 28 July 2014) at 2, online: <www.aboriginal. alberta.ca/documents/First Nations Consultation Guidelines LNRD.pdf.pdf $>$.

Impact benefit agreements may include a variety of provisions and can be referred to in many ways including participation agreements, project agreements or co-operation agreements.

To date, these agreements have generally been confidential between the parties. Accordingly, these statements and the practical advice regarding commercial agreements generally are based on the authors' practice experience in this area.

See e.g. Collaboration Agreement between the Northern Village of Pinehouse and Kineepik Métis Local Inc. and Cameco Corporation and Areva Resources Canada Inc, (12 December 2012), online: Village of Pinehouse Lake <www.pinehouselake.com/wp-content/uploads/2015/05/Collaboration-Agreement. pdf $>$ at 9 . 
good consultation practices and the willingness to enter into these agreements, energy developments today regularly experience significant legal and regulatory challenges.

\section{WHY CANADA'S APPROACH INCREASES RISK TO ENERGY DEVELOPERS}

While the current law of consultation and accommodation provides for the right to be meaningfully consulted on energy development, the jurisprudence to date has not included a requirement to obtain the informed consent of Aboriginal communities to the proposed activity on their traditional lands - except on those lands where the group holds a form of "title" to the lands (for example, First Nation reserve lands, Alberta Métis settlement lands, fee simple settlement lands, and lands where Aboriginal title has been judicially established).

On surrendered treaty lands, where a First Nation may have a treaty right to hunt and fish on unoccupied Crown land within its traditional territory, the First Nation does not have a right to informed consent. Rather, the First Nation may have the right to be meaningfully consulted and accommodated but only if those treaty rights are potentially impacted. ${ }^{22}$ Even in the case of serious impact, the right to be consulted does not necessarily amount to a right to informed consent or a "veto" over what can be done on the land as the duty to consult does not require reaching agreement. ${ }^{23}$ Aboriginal and treaty rights are simply not absolute and can be infringed by the federal government and provincial governments, if justified. ${ }^{24}$ While treaty rights need to be respected, the Crown is not rendered "impotent", and can generally continue to take up and manage the lands and resource in question to balance broader societal interests. $^{25}$

Even in the case of impact to Aboriginal title lands or on-reserve and settlement lands, where informed consent is required by government or third parties seeking to use the land, governments can justify overriding the affected Aboriginal community's wishes in favour of the broader public good where the Aboriginal title holder or leadership does not provide its informed consent to the use. ${ }^{26}$ Other than in a few, exceptional cases ${ }^{27}$ Canadian Aboriginal peoples generally do not have a clear, unqualified right to informed consent within their traditional lands. ${ }^{28}$

Accordingly, while the existing constitutional framework affords some degree of protection for Aboriginal interests in Canada, that protection is limited and, in most areas of Canada, does not readily align with the aspirations and expectations of the impacted Aboriginal communities, particularly in the context of international human rights as they are

To "accommodate" generally means to "adapt, harmonize, or reconcile." A commitment to the process of accommodation does not require reaching an agreement: see Haida, supra note 15 at para 49.

Ibid at para 48 .

$R v$ Sparrow, [1990] 1 SCR 1075 at 1110.

Grassy Narrows First Nation v Ontario (Natural Resources), 2014 SCC 48, [2014] 2 SCR 447 at paras $50-52$.

Tsilhqot'in, supra note 9 at para 77 .

27 On settlement lands, the beneficiaries typically have the right to control access on at least a portion of the settlement lands.

28 The authors readily acknowledge the complexity of determining which Aboriginal communities should have the right to informed consent within their traditional lands when those traditional lands are shared, and the impacts of any given energy development may be experienced to a greater degree by some communities than others. 
commonly understood by those communities. Notwithstanding that a treaty may have modified the scope and protection of their rights within their traditional lands, Aboriginal communities consistently expect to participate in and benefit from energy and natural resource development on their traditional lands - or at least to be provided with a mechanism to share in the revenues generated. Aboriginal communities are also seeking rights of co-management and environmental stewardship, and demanding respect for such Indigenous sustainability concepts as living in close harmony with and on the land, fulfillment of their responsibility to their succeeding seventh generation and shared use of the land.

While many political and practical initiatives between Canadian and Aboriginal governments are taking place in an attempt to resolve the apparent disconnect in expectations with Aboriginal communities, ${ }^{29}$ the legal and regulatory frameworks have not yet evolved to where they satisfy Aboriginal aspirations. Until they do, it appears that energy developers will continue to face increasing Aboriginal above ground risk. In our view, the degree of above ground risk facing energy developers today warrants a considered examination of international approaches and, in particular, a solution that effectively progresses the principle of informed consent within the context of the current Canadian legal framework.

\section{RESPECTING TRADITIONAL LANDS From a Human Rights Perspective}

This section will provide an overview of the international movement towards, and momentum behind, recognizing the UN Declaration as a minimum human rights standard, and, in particular, the obligation of governments to consult with, and where appropriate, obtain the informed consent of Indigenous peoples affected by energy development. This section also introduces the "UN Global Compact" as a policy initiative developed for energy developers and other businesses committed to aligning their operations and strategies with human rights principles increasingly accepted by the international community. ${ }^{30}$

\section{A. The United Nations Declaration on the Rights OF INDIGENOUS PEOPLES}

In recognition of the status of Indigenous peoples as culturally distinct and selfdetermining, and of their unique historical challenges, the global human rights community developed the UN Declaration over a 25-year period prior to its adoption in 2007. The UN Declaration affirms the view of the international community that Indigenous peoples require recognition of their collective rights as a people in order for them to fully enjoy their individual human rights. The UN Declaration does not seek to create new or special rights 
for Indigenous peoples, but rather elaborates on existing human rights standards and articulates them as they apply to the particular situation of Indigenous peoples. ${ }^{31}$

There is considerable disagreement in the international legal community as to the legal and practical effect of the UN Declaration. Many view it as an aspirational document only, with no legal binding effect unless it has been incorporated into domestic law. ${ }^{32}$ Other experts argue that it has already become part of customary international law and accepted as law in general practice. ${ }^{33}$ Even as a non-binding instrument, the UN Declaration nevertheless can provide legal context for courts in interpreting domestic legislation. ${ }^{34}$

While recognizing the subtleties associated with the legal effect of the UN Declaration, for the purposes of this article, it is sufficient to accept that UN "declarations" reflect broadly supported principles to which the signatory member states wish to give recognition and support. It follows that the UN Declaration, and in particular its reliance on informed consent, can be taken, at a minimum, to reflect the global community's expression of the nature and extent of human rights to be afforded Indigenous peoples, including affected Aboriginal communities, in respect of energy developments on their traditional lands.

\section{B. The Principle of Free, Prior, And Informed Consent}

For the purposes of this article, the elements of informed consent relevant to development on traditional lands are included in Article 32 of the UN Declaration:

1. Indigenous peoples have the right to determine and develop priorities and strategies for the development or use of their lands or territories and other resources.

2. States shall consult and cooperate in good faith with the indigenous peoples concerned through their own representative institutions in order to obtain their free and informed consent prior to the approval of any project affecting their lands or territories and other resources, particularly in connection with the development, utilization or exploitation of mineral, water or other resources.

UN Global Compact, A Business Reference Guide: United Nations Declaration on the Rights of Indigenous Peoples (New York: United Nations Global Compact Office, 2013) at 5, online: $<$ https://www.unglobalcompact.org/docs/issues_doc/human_rights/IndigenousPeoples/BusinessGuide. pdf $>$ [UN Business Guide].

32 UNGAOR, 61st Sess, 107 Plen Mtg, UN Doc A/61/PV.107 (2007). Prior to the vote on the UN Declaration, the Representative of Australia, Robert Hill, stated: "[I]t is the clear intention of all States that it be an aspirational declaration with political and moral force but not legal force" (ibid at 12); and by Rosemary Banks, the Representative of New Zealand it was stated: "The Declaration is explained by its supporters as being an aspirational document intended to inspire rather than to have legal effect" (ibid at 14). See also Stephen Allen, "The UN Declaration on the Rights of Indigneous Peoples and the Limits of the International Legal Project" in Stephen Allen \& Alexandra Xanthaki, eds, Reflections on the UN Declaration on the Rights of Indigenous Peoples (Portland: Hart, 2011) 225 at 228.

33 See e.g. James Anaya, "Indigenous Peoples' Participatory Rights in Relation to Decisions about Natural Resource Extraction: The More Fundamental Issue of What Rights Indigenous Peoples have in Lands and Resources" (2005) 22:1 Ariz J Intl \& Comp L 7.

34 The Supreme Court of Canada has made it clear in Baker $v$ Canada (Minister of Citizenship \& Immigration), [1999] 2 SCR 817 that "[i]nternational treaties and conventions are not part of Canadian law unless they have been implemented by statute" (ibid at para 69). The Supreme Court of Canada observed that "values reflected in international human rights law may help inform the contextual approach to statutory interpretation and judicial review" (ibid at para 70). Lower courts are not recognizing the UN Declaration as having any legal effect: see e.g. Sackaney $v$ The Queen, 2013 TCC 303, 2013 DTC 1240 at para 35; Snuneymuxw First Nation v The Queen in Right of British Columbia, 2004 BCSC 205, 116 CRR (2d) 237. 
3. States shall provide effective mechanisms for just and fair redress for any such activities, and appropriate measures shall be taken to mitigate adverse environmental, economic, social, cultural or spiritual impact. $^{35}$

When compared to other communities or ethnic groups, indigenous peoples are particularly prone to experience adverse impacts from energy development both because they typically have a special ${ }^{36}$ and fundamental relationship with their "lands and territories,"37 and because they often suffer from discrimination and a systemic lack of representation from and within government and legal institutions. Obtaining the informed consent of affected Indigenous communities should be viewed as part of a larger process that provides special protection for Indigenous peoples assuring that a broad spectrum of internationally recognized human rights are being protected. ${ }^{38}$

While the UN Declaration is primarily intended to address the role of governments engaging with Indigenous peoples, the broad international support for the UN Declaration is an indication that, regardless of its status under any particular domestic law, obtaining informed consent can be viewed as a process whereby the prudent energy developer can avoid the appearance of being involved or complicit in practices or activities inconsistent with international human rights. On a practical level, obtaining the informed consent of affected indigenous communities has become relevant to energy developers because civil society, the financial community and various other stakeholders, as well as the affected Indigenous communities themselves, increasingly hold the expectation that informed consent will be obtained. Energy developers that proactively adjust their approach to reflect this emerging new paradigm for Aboriginal engagement, and proactively adhere to internationally accepted human rights standards notwithstanding the status of domestic law, can protect their businesses by minimizing a significant source of above ground risk.

\section{CANADA's QuALIFIED ACCEPTANCE OF THE UN DECLARATION}

The UN Declaration was initially opposed in 2007 by only four member states, namely Canada, Australia, New Zealand and the United States, each having large, non-Indigenous immigrant majorities and small remnant Indigenous populations. The statement issued by Canada at that time can be viewed as an unwillingness to engage in a re-balancing of individual rights versus collective rights within Canada's constitutional framework:

UN Declaration, supra note 5, art 32.

The relationship of Indigenous peoples to the lands is said to form a core part of their identity and spirituality and to be deeply rooted in their culture and history: see UNESC, Permanent Forum on Indigenous Issues, Indigenous Peoples, Indigenous Issues: Backgrounder, 6th Sess, online: <www.un. org/en/events/indigenousday/pdf/Backgrounder LTNR FINAL.pdf>.

For clarity, the authors wish to emphasize the distinction between the phrase "lands and territories" used in the UNDeclaration and the term "traditional lands" used elsewhere in this article; as alluded to above, Canadian legislation and judicial decisions essentially limit "informed consent" lands to Aboriginal title and reserve/settlement lands, while the term "lands and territories" used in the UN Declaration may be more broadly interpreted in the international context.

United Nations Global Compact, Indigenous Peoples' Rights and the Role of Free, Prior and Informed Consent, by Amy K Lehr, (endorsed by the United Nations Global Company Human Rights and Labour Working Group on 20 February 2014), online: <www.unglobalcompact.org/docs/issues_doc/human rights/Human_Rights_Working_Group/FPIC_Indigenous_Peoples_GRN.pdf $>$. 
Canada will vote against adoption of the current text because it is fundamentally flawed and lacks clear, practical guidance for implementation, and contains provisions that are fundamentally incompatible with Canada's constitutional framework. It also does not recognize Canada's need to balance indigenous rights to lands and resources with the rights of others.

Canada supports the spirit and intent of a United Nations Declaration on the Rights of Indigenous Peoples. But further negotiations are necessary in order to achieve a text worthy of Canadian support that will truly address the interests of indigenous and non-indigenous peoples in Canada and around the world. ${ }^{39}$

All four opposing countries have since moved to endorse the UN Declaration in some way, with Canada formally issuing a reluctant statement of support in $2010 .{ }^{40}$ In the accompanying backgrounder, Canada described the UN Declaration as an "aspirational document because it has the potential to contribute positively to the advancement of indigenous rights around the world," international law, nor did it affect any change to Canadian laws:

In 2007, at the time of the vote during the United Nations General Assembly, and since, Canada placed on record its concerns with various provisions of the Declaration, including provisions dealing with lands, territories and resources; free, prior and informed consent when used as a veto; self-government without recognition of the importance of negotiations; intellectual property; military issues; and the need to achieve an appropriate balance between the rights and obligations of Indigenous peoples, States and third parties. These concerns are well known and remain. However, we have since listened to Aboriginal leaders who have urged Canada to endorse the Declaration and we have also learned from the experience of other countries. We are now confident that Canada can interpret the principles expressed in the Declaration in a manner that is consistent with our Constitution and legal framework. ${ }^{42}$

Canada's qualified endorsement of the UN Declaration falls short of adopting it wholly into domestic law, and perhaps reflects the legal and practical challenges inherent in aligning the UN Declaration's principles with Canada's established constitutional framework for protecting Aboriginal interests. It does not follow, however, that the UN Declaration is not having a tangible impact in Canada. Aboriginal leaders and the Truth and Reconciliation Commission of Canada are calling for its adoption ${ }^{43}$ and a recent Private Member's Bill calls for "the Government of Canada to take all measures necessary to ensure that the laws of Canada are consistent with the United Nations Declaration on the Rights of Indigenous

39 Aboriginal Affairs and Northern Development Canada, "Statement by Canada's New Government Regarding the United Nations Declaration on the Rights of Indigenous Peoples," by Philippe Mailhot (Ottawa: AANDC, 12 September 2007), online: Government of Canada <nouvelles.gc.ca/web/articleen.do?crtr.sj1D=\&mthd=advSrch\&crtr.mnthndVl=\&nid=349509\&crtr.dpt1D=\&crtr.tp1D=\&crtr.lc1 $\mathrm{D}=\&$ crtr.yrStrtVl=2008\&crtr.kw=\&crtr.dyStrtVl=26\&crtr.aud1D=\&crtr.mnthStrtVl=2\&crtr.yrndVl $=\&$ crtr.dynd $\mathrm{Vl}=>$.

$40 \quad$ Indigenous and Northern Affairs Canada, "Canada's Statement of Support on the United Nations Declaration on the Rights of Indigenous Peoples" (Ottawa: INAC, 12 November 2010), online: <https:// www.aadnc-aandc.gc.ca/eng/1309374239861/1309374546142>.

Ibid.

Ibid.

Truth and Reconciliation Commission of Canada, Truth and Reconciliation Commission of Canada: Calls to Action (Winnipeg: TRC, 2015), online: <www.trc.ca/websites/trcinstitution/File/2015/Findings/ Calls to Action English2.pdf $>$. 
Peoples. ${ }^{444}$ Further, the recently elected Alberta New Democratic government ${ }^{45}$ and federal Liberal government ${ }^{46}$ have both taken steps to implement the UN Declaration. In our view, the principles in the UN Declaration increasingly articulate the world view of Indigenous cultures and explain the fundamental respect and involvement in resource development and environmental stewardship that drives Indigenous community expectations. Until these expectations are resolved politically and legally within each member country, energy developers are left to manage Aboriginal above ground risk on their own through the implementation of corporate policies and commercial arrangements that anticipate the future direction of domestic law.

\section{CORPORATE INITIATIVES TO RESPECT HUMAN RightS}

The UN Compact is a strategic policy initiative developed in 2000 for businesses that are committed to aligning their operations and strategies with ten universally accepted principles derived from the United Nations Universal Declaration of Human Rights, ${ }^{47}$ the International Labour Organization's Declaration on Fundamental Principles and Rights at Work, ${ }^{48}$ the Rio Declaration on Environment and Development,${ }^{49}$ and the United Nations Convention Against Corruption. ${ }^{50}$ With over 12,000 current corporate participants and other stakeholders from over 145 countries, the UN Compact is the largest voluntary corporate responsibility initiative in the world, providing an established and globally recognized policy framework for the development, implementation, and disclosure of environmental, social and governance corporate policies designed to help advance sustainable business models and markets.

The first two principles of the UN Compact, which are derived from the Declaration of Human Rights, are intended to address the rights of Indigenous peoples, namely: (1) that "[b]usinesses should support and respect the protection of internationally proclaimed human rights"; and (2) that businesses should ensure that "they are not complicit in human rights abuses." ${ }^{, 1}$ A key observation for energy developers is that proceeding with an energy development on the basis of compliance with narrow domestic law could lead to involvement

44 Bill C-641, An Act to ensure that the laws of Canada are in harmony with the United Nations Declaration on the Rights of Indigenous Peoples, 2nd Sess, 41st Parl, 2014 (defeated as of 6 May 2015), online: Parliament of Canada <www.parl.gc.ca/HousePublications/Publication.aspx?Language=E\& Mode $=1 \&$ docid $=681792 \&$ File $=4>$.

45 Letter from Rachel Notley, Premier of Alberta, to the Cabinet Ministers of Alberta (7 July 2015), online: Alberta Aboriginal Relations < aboriginal.alberta.ca/documents/Premier-Notley-Letter-Cabinet-Ministers .pdf $>$.

46 Mandate letter from Justin Trudeau, Prime Minister of Canada, to Carolyn Bennett, Minister of Indigenous and Northern Affairs [nd], online: Prime Minister of Canada <pm.gc.ca/eng/ministerindigenous-and-northern-affairs-mandate-letter $>$.

47 GA Res 217 (III), UNGAOR 3rd Sess, Supp No 33, UN Doc A/810, (1948), online: United Nations $<$ www.un.org/en/documents/udhr/index.shtml $>$ [Declaration of Human Rights].

48 International Labour Organization, ILO Declaration on Fundamental Principles and Rights at Work, 86th Sess, International Labour Conference (18 June 1998), online: <www.ilo.org/declaration/ thedeclaration/lang--en/index.htm>.

49 UN Commission on Human Rights, Human rights and the environment, UNHCR, 51st Sess, UN Doc E/CN.4/RES/1995/14 (1995), online: <www.refworld.org/docid/3b00f0cc14.html >.

50 United Nations Convention Against Corruption, GA Res 58/4, UNGAOR, 58th Sess, UN Doc A/Res/58/4 (2003), online: <www.unodc.org/unodc/en/treaties/CAC/>.

51 United Nations Global Compact, "The Ten Principles of the UN Global Compact," online: <www.un globalcompact.org/what-is-gc/mission-principles $>$. 
in practices or activities inconsistent with commonly accepted international human rights norms. $^{52}$

In 2011, the United Nations Human Rights Council unanimously endorsed the United Nations Guiding Principles on Business and Human Rights ${ }^{53}$ as a global standard for preventing and addressing the risk of adverse impacts on human rights linked to business activity. The UN Principles recognize each member state's obligation to respect, protect, and fulfil human rights and fundamental freedoms, and that all business enterprises are obligated to comply with all applicable domestic laws and to respect human rights. The UN Principles enumerate foundational principles of the corporate responsibility to respect human rights, and suggest that, in setting internal corporate policies, businesses must accept that where domestic law falls short of international human rights norms, the best practice is to insist that the higher international standard is adhered to in order to reduce or eliminate above ground risk.

In 2013, the UN Compact launched the UN Business Guide aimed at increasing the understanding among businesses of the rights of indigenous peoples around the globe, clarifying the responsibility of businesses in relation to the rights of Indigenous peoples, and to provide practical suggestions for respecting and supporting those rights in the context of internal corporate policy. The UN Business Guide specifies key actions that are foundational to respecting the human rights set out in the UN Declaration, including a commitment to obtaining, and maintaining, the informed consent of indigenous peoples for energy developments that affect their rights. ${ }^{54}$

The UN Compact, the UN Principles, and the UN Business Guide provide a clear framework for energy developers in formulating corporate policies that reflect internationally-accepted best practices for ensuring respect for the individual and collective rights of Indigenous peoples. Any failure by an energy developer to respect these best practices increases the risk of not meeting the expectations of Aboriginal communities, and in extreme circumstances, increases the risk that its involvement may be viewed as inconsistent with internationally accepted human rights norms.

\section{The Business CASE For AlignMent}

While the moral and ethical argument for obtaining informed consent without the force of Canadian domestic law may be compelling, it has not yet resulted in Canadian energy

52 By way of example, an extreme factual circumstance can be conceived where an energy development, while fully approved by domestic law, leads to the complete inability to exercise an Indigenous right on traditional lands or the total destruction of a species that is key to the cultural survival of an Indigenous community (by cumulative effect, or otherwise), which in turn eventually results in permanent damage to their livelihood or very existence. On the face of it, participation in this energy development would likely be viewed by Indigenous communities or the international human rights community as inconsistent with, if not a violation of, international human rights. It follows that any similar fact pattern that has not yet resulted in demonstrated permanent damage may nonetheless be viewed by Indigenous communities and the international human rights community as a "pending" failure to observe human rights standards that can nonetheless lead to the reputational damage.

53 Guiding Principles on Business and Human Rights: Implementing the United Nations "Protect, Respect and Remedy" Framework, UNHRC, 17th Sess, Annex, UN Doc A/HRC/17/31 (2011) 6, online: <www. ohchr.org/Documents/Publications/ GuidingPrinciplesBusinessHR_EN.pdf $>$ [UN Principles]. Supra note 31 at 11 . 
developers, on a consistent basis, acting in a manner that fully respects the most robust interpretation of the human and collective rights of affected Aboriginal communities from an international perspective. Accurately assessing Aboriginal above ground risk, as well as the creation of incremental value through commercial relationships, from a purely economic perspective, on the other hand, may provide the needed incentive and rationale for energy developers to proactively seek and obtain informed consent.

\section{A. Impact of Above Ground Risk on Market Value}

A significant and growing body of research confirms that the effect of Indigenous above ground risk on energy developers who fail to obtain informed consent prior to operating on traditional lands is tangible, predictable, significant, and increasing. ${ }^{55}$ This ultimately results in construction cost escalation, degradation of operating profits, reputational damage, a higher cost of capital, and a discount on monetization. The research also demonstrates that energy developers may not be accurately assessing and accounting for the full range of costs associated with these above ground risks including lost productivity due to temporary shutdowns or delay, opportunity costs in terms of the lost value linked to future projects, inability to timely implement expansion plans, frustrated monetization or exit transactions, and indirect costs resulting from staff and senior management time being diverted to managing conflict.

While largely focused on international extractive projects, many such research publications include references to Canadian companies and projects, and there is no logical rationale for distinguishing the conclusions reached in respect of international resource developments from energy developments in Canada. Hundreds of millions of dollars have been lost in Canada due to project deferrals and operational delays, and in some instances proposed energy developments have all but been abandoned due to the above ground risks created by resistance from affected Aboriginal communities. While it appears self-evident that the value of a company increases when it cooperates effectively with local and Aboriginal communities to minimize above ground risk, there remains considerable reluctance among Canadian energy developers to treat efforts undertaken to reduce Aboriginal above ground risk and ensure a long-term, stable social licence as an economic investment with measurable financial returns. Obtaining informed consent, and the associated alignment of interests that result from the formation of mutually beneficial commercial ventures mitigates the potential for Aboriginal above ground risk, and lays the foundation for a long-term, sustainable project that provides meaningful benefits for both the energy developer and the affected Aboriginal community.

\section{B. Capital Provider Requirements}

Increasingly, domestic law consultation requirements that fall short of international standards of obtaining informed consent similarly fall below the expectations of the

55 See e.g. Rachel Davis \& Daniel Franks, Costs of Company-Community Conflict in the Extractive Sector (Cambridge: CSR Initiative at the Harvard Kennedy School, 2014), online: Harvard Kennedy School $<$ www.hks.harvard.edu/m-rcbg/CSRI/research/Costs\%20of\%20Conflict_Davis\%20\%20Franks.pdf $>$. 
institutions that provide debt or equity financing to energy developers. ${ }^{56}$ It follows that, to the extent acceptable investment returns can be maintained, capital providers will ultimately be more willing to provide financing to energy developers with a demonstrated record of obtaining informed consent in a manner that leads to ongoing, positive relations with affected Aboriginal communities.

Launched in 2006, the United Nations supported "Principles for Responsible Investment Initiative" $" 57$ is an international network of institutional capital providers putting six "Principles for Responsible Investment" into practice on the basis of their fiduciary duty to act in the best long-term interests of their beneficiaries. ${ }^{58}$ The signatories to the PRII initiative recognize that environmental, social and governance issues can affect the performance of investment portfolios and that, while the market-based economy has emerged as the most efficient system for allocating scarce economic resources, the generation of longterm sustainable returns is dependent on stable, well-functioning and well governed social, environmental, and economic systems. ${ }^{59}$

Investment analysts are increasingly recognizing the significance of informed consent in evaluating above ground risks associated with Indigenous rights in their methodology. ${ }^{60}$ Mounting evidence of the financial materiality of environmental, social, and governance issues, alongside growing demands for more sustainable approaches to investment, are among the key drivers behind the adoption of responsible investment practices worldwide. Increasingly, investors concerned about the impact of short-termism within investment research, asset allocation, and performance monitoring recognise that integrating environmental, social and governance issues into both investment analysis and stewardship practices forms part of their fiduciary duty to clients and beneficiaries and insist on their portfolios being managed in a way that systematically assesses drivers of risk and return over longer timeframes.

Similar in concept to the PRII, the "Equator Principles" is a risk management framework for capital providers in determining, assessing and managing environmental, social, and governance risk in projects, primarily as a minimum standard for due diligence to support responsible risk decision-making. ${ }^{61}$ Adopted by 81 capital providers in 36 countries, the Equator Principles have greatly increased the attention and focus on environmental, social, and governance issues, including setting standards for relations with locally affected

56 In this article, the term "capital providers" refers to those institutions providing debt or equity financing in respect of energy developments.

UNEP, "Principles for Responsible Investment Initiative," online: <www.unpri.org > [PRII].

See UNEP, Principles for Responsible Investment, The Six Principles, online: PRII $<$ www.unpri.org/ about-pri/the-six-principles/>.

PRII, supra note 57. Signatories to the Investment Principles include such significant Canadian institutions as Alberta Investment Management Corporation, British Columbia Investment Management Corporation, British Columbia Municipal Pension Plan, Caisse de dépôt et placement du Québec, Canada Pension Plan Investment Board, Healthcare of Ontario Pension Plan, Ontario Teachers' Pension Plan, and the Public Sector Pension Investment Board.

60 See Sheila Stefani, "Indigenous rights: risks and opportunities for investors"(June 2009), online: Ethical Investment Research Services <www.eiris.org/files/research\%20publications/indigenousrightsjun09. pdf $>$.

$61 \quad$ Equator Principles Association, "Equator Principles: Environmental and Social Risk Management for Projects," online: <www.equator-principles.com> ["Equator Principles"]. 
indigenous communities. ${ }^{62}$ The Equator Principles recognize that projects affecting indigenous peoples must be subject to a process of "Informed Consultation and Participation," 63 and the need to comply with the rights and protections for indigenous peoples contained in relevant domestic law, including those laws implementing host country obligations under international law. Consistent with the policy and performance standards of the International Finance Corporation (IFC) of the World Bank Group, energy developments with adverse impacts on indigenous people require the informed consent of those communities when warranted. ${ }^{64}$ Subject to a significant "Designated Country" exception, participating capital providers commit to implementing the Equator Principles in their internal environmental, social and governance corporate policies and in their standards for financing projects, and undertake not to provide finance for projects where the energy developer will not, or is unable to, comply with the Equator Principles $2013 .{ }^{65}$

The PRII, the Equator Principles, and the IFC performance standards can serve as a readily available template for proactive energy developers anticipating more stringent requirements from its capital providers and seeking to proactively implement progressive corporate policies.

\section{The Opportunity: Shared Value Creation}

In contrast to above ground risk which represents the "stick" or negative consequence of failing to obtain informed consent from affected Aboriginal communities, shared value is the "carrot" incentivizing energy developers to implement the steps necessary to obtain informed consent notwithstanding domestic law. ${ }^{66}$ Energy developers in commercial relationships with affected Aboriginal communities form closer relationships and partnerships and accordingly benefit from improved understanding and alignment of interests, which can translate into predictable timelines for project permitting and commencement of operations, and ultimately better commercial returns over the long-term.

Shared value is not about redistributing corporate value through philanthropy, or about including stakeholders' values in corporate decisions through corporate social responsibility initiatives, both of which presumably represent a net business cost which must be traded-off

Ibid. The Equator Principles have been adopted by such significant Canadian institutions as Bank of Montreal, Bank of Nova Scotia, Canadian Imperial Bank of Commerce, Manulife Financial, Royal Bank of Canada and TD Bank Financial Group.

Finator Principles June 2013: A financial industry benchmark for determining, assessing and managing environmental and social risk in projects (4 June 2013) at 7, online: $<$ www.equator-principles.com/resources/equator principles III.pdf $>$ [Equator Principles 2013]. International Finance Corporation, Performance Standard 7: Indigenous Peoples (1 January 2012), online: $<$ www.ifc.org/wps/wcm/connect/1ee7038049a79139b845faa8c6a8312a/PS7_English_2012.pdf ?MOD=AJPERES $>$.

Supra note 63 at 2.

In this article, the term "shared value" refers to the management strategy described in Michael E Porter \& Mark R Kramer in an article entitled "Creating Shared Value," Harvard Business Review (January 2011) 62, online: $<$ https://hbr.org/2011/01/the-big-idea-creating-shared-value $>$. Shared value focuses on creating measurable financial value by identifying and addressing environmental, social and governance issues that intersect with a company's business, and is defined as "policies and operating practices that enhance the competitiveness of a company while simultaneously advancing the economic and social conditions in the communities in which it operates" (ibid at 66). Corporate social responsibility programs, which primarily focus on reputation with only a limited connection to the business, are distinguished from shared value creation in that shared value "is integral to a company's profitability and competitive position. It leverages unique resources and expertise of the company to create economic value by creating social value" (ibid at 76). 
against the associated return or profitability. The shared value framework instead focuses on the creation of meaningful new economic and social benefits that exceed the costs of creating and implementing those benefits for both the business and society. Rather than focus on mitigating the harm caused by a company's existing operations, or on compensating society for perceived damage done during the course of business, shared value strategies seek to benefit society and increase financial returns at the same time.

Energy developers operate in some of the most underdeveloped regions on earth, with many of the countries and communities in which they operate facing significant challenges in health, education, economic development, and basic infrastructure. These same extractive industries are losing billions to above ground risk despite extensive philanthropic and corporate social responsibility initiatives. Extractive companies can implement shared value initiatives by pursuing opportunities that tie business success to the prosperity of host communities and countries, often working in collaboration with governments, multilateral institutions, non-profit organizations, and even competitors. ${ }^{67}$ The failure of an energy developer to align with the communities in which it operates creates real business costs, some obvious (for example, conflicts with local communities that see no benefits from energy development) and some subtler (for example, the added costs of sourcing goods and services from uncompetitive local suppliers, employing an expatriate workforce at a premium due to lack of local talent).

Shared value in the context of informed consent presents enormous opportunities for Canadian energy development over the coming decades as the nature and extent of Aboriginal interests continues to evolve and impact a significant and growing land and resource base. There are 26 modern treaties and self-government agreements that cover over 50 percent of Canada's land mass, and many provide Aboriginal communities with rights or outright control over surface and subsurface resources. The 585 Canadian First Nations live on a total land base of 3.5 million hectares, an area that has grown nearly 25 percent since 1990, and which is expected to continue growing through treaty land entitlement, additions to reserve and land claims. ${ }^{68}$ The proximity of Canada's untapped energy development potential to Aboriginal communities is remarkable, with Aboriginal peoples making up anywhere from 34 percent to 95 percent of the population in northern and remote areas of Canada ${ }^{69}$ Both the Fraser Institute and Natural Resources Canada ${ }^{70}$ estimate that over the ensuing decade more than 600 major energy development projects, valued at over $\$ 650$ billion, are planned for Canada, and each one proposed is set to take place in or near one or more Aboriginal communities. The challenge for Canadian energy developers lies in accurately assessing and measuring, from a shared value perspective, the investment return on obtaining informed consent.

67 Shared Value Initiative, Extracting with Purpose: Creating Shared Value in the Oil and Gas and Mining Sectors' Companies and Communities (October 2014) at 3, online: <www.sharedvalue.org/resource/ report-extracting-purpose>.

68 The National Aboriginal Economic Development Board, Increasing Aboriginal Participation in Major Resource Projects (October 2012), online: <www.naedb-cndea.com/reports/increasing-aboriginalparticipation-in-major-resource-projects.pdf $>$.

69 Ravina Bains, "Opportunities for First Nations Prosperity through Oil and Gas Development" (Fraser Institute, November 2013) at 5, online: <www.fraserinstitute.org/sites/default/files/ opportunities-forfirst-nation-prosperity-through-oil-and-gas-development.pdf $>$.

70 Ibid at iii; Natural Resources Canada, "Key Facts and Figures on the Natural Resources Sector" (20 July 2015), online: <www.nrcan.gc.ca/publications/key-facts/16013>. 


\section{Structuring Commercial Relationships With Aboriginal Communities}

The authors submit that energy developers seeking to undertake activities on traditional lands are able to obtain the informed consent of affected Aboriginal communities - and thereby minimize Aboriginal above ground risk and create incremental shared value - by structuring commercial relationships that align the long-term interests of the energy developer with those of the affected Aboriginal communities. This section will provide an overview of certain broad principles that energy developers may wish to consider when structuring, negotiating, and implementing those commercial relationships.

\section{A. UniQue Legal, Historical, and Cultural Context}

While recognizing that each Canadian Aboriginal community has a unique history shaping its particular cultural identity, there are a number of general characteristics and attributes that can be recognized, understood, and respected by energy developers in the course of seeking to implement successful commercial relationships. Foremost is the observation that Canada's Aboriginal communities are indigenous, communal societies with distinct cultures, traditions, language, needs and desires, capacities, challenges and economic opportunities, and that they enjoy varying degrees of sovereignty, fiscal responsibility, and institutional maturity. As the first peoples of Canada, they played a fundamental role in the formation of our nation and, as a consequence, enjoy a unique legal status and relationship with the governments of Canada that must be considered and appreciated in order to understand who they are as peoples and how they have come to view energy development on their traditional lands.

Energy developers accustomed to process-oriented consultation and accommodation engagement with Aboriginal communities must recognize that different considerations will apply in the context of a commercial negotiation. While some Aboriginal governments enjoy the full powers of self-government, many others are statutorily regulated and must conduct themselves within the confines and limits of those statutory constraints. While most Aboriginal governments have the legal capacity to contract on behalf of its membership, material business decisions must be passed by a majority of Council at a duly convened meeting evidenced by a band council resolution. ${ }^{71}$ Significant decisions, either because of a legal requirement or the desire of Chief and Council to garner widespread community support, may need to be ratified through a community referendum. Each community will also have a different level of capacity, business acumen, and sophistication based on their experiences to date, the character, quality and integrity of their advisors, and the structure of their government and bureaucracy.

Prudent energy developers must also become familiar with the variety of legal and regulatory structures within which energy development takes place across Canada. In northern Canada, modern settlement agreements have created statutory requirements for land use planning, access, environmental assessment and review processes, consultation, and the 
negotiation of impact benefit agreements. ${ }^{72}$ There are also several legislative initiatives in place to support and promote business on and within Aboriginal communities. ${ }^{73}$

Aboriginal governments also engage in and do business differently than corporations. They are governments, and, in many respects, when seeking illustrative parallels most closely resemble sparsely populated, large land base municipalities with a culturally homogenous constituency and restrictive enabling legislation in the Indian Act. In this respect energy developers must identify and navigate political complexities, statutory constraints, divergent agendas, family loyalties, community pressure points, and powerful individuals, as it would in contracting with any municipality. Each factor plays a significant role in how a proposed commercial relationship is perceived and understood by the community, and like any transaction, early and thorough due diligence on the counterparty is important and pays dividends in terms of a successful, long-term relationship. Aboriginal governments are also obviously Aboriginal, and as an Indigenous culture are primarily relationship-based, as distinguished from the corporate, "task based" culture that most North American and global energy developers exhibit. It follows that establishing trust early in the process, and moving forward in an open, collaborative, and respectful manner are critical components of building a successful commercial relationship. Finally, each Aboriginal community and the individual members within that community may also have a different level of trust (usually low) with commercial proposals, and in particular with respect to energy development, reflecting their past collective and individual experience (usually bad). Historical internal transparency issues and politics may also play a significant role in messaging, consensus building and ultimately in community acceptance.

We therefore contend that the historical, legal, and cultural contexts of Canada's Aboriginal peoples must be understood and appreciated by an energy developer before embarking on a commercial relationship in the same way that one would not go to a foreign sovereign and attempt to do business without first coming to a basic understanding of that jurisdiction's legal and social constructs, as well as the individuals filling key roles within the executive and administrative branches of government.

\section{B. GOVERNANCE, LEADERSHIP, AND BUILDING COMMUNITY SUPPORT}

Entering into long-term, successful commercial relationships with affected Aboriginal communities is largely an exercise in understanding the needs of that community, investing the time to adequately inform and, where necessary, educate that community and build consensus, and ultimately develop a level of trust that allows the energy developer to connect

72 See e.g. the Western Arctic Claim: Inuvialuit Final Agreement as Amended (15 January 1987), online: Inuvlaluit Land Administration $<w w w$.inuvialuitland.com/resources/Inuvialuit Final Agreement.pdf $>$ (proposed energy developments on Inuvialuit Lands are subject to an environmental impact screening and review process, and developers must conclude a valid Participation Agreement setting out the rights and obligations of the parties respecting the activity for which the access is being granted. The terms of the agreement may include: wildlife compensation, restoration and mitigation; employment, service and supply contracts; education and training; and equity participation or other similar types of participatory benefits).

73 See e.g. First Nations Commercial and Industrial Development Act, SC 2005, c 53 (provides a framework for a First Nation community to pursue industrial development on its reserve lands when there is a gap between federal and provincial regulatory regimes). 
with the community as a whole. In order to build this requisite community consensus and support needed to pursue energy development with Aboriginal communities, it is important to understand their governance and leadership models. First Nations, for the most part, operate within a statutorily imposed governance structure, but one that remains heavily influenced by traditional decision making. As a government, notionally akin to a municipal government, they are an elected body burdened with all the same issues as other local governments: a vocal electorate demanding responses and solutions to pressing collective community needs including health, education, housing, drinking water, social support, and infrastructure. A key distinction, however, is that Aboriginal governments are largely without the usual tax base for a revenue source, being almost entirely funded through moneys provided by the federal government. Most Aboriginal governments struggle to access meaningful capital for infrastructure and internally generated business development opportunities, largely as a consequence of their inability to pledge assets as security, or their unwillingness to risk assets for investment.

The dynamic of having an elected government's sole source of funding being set at the discretion of the federal government sets up a never-ending tension around the adequacy and use of that funding, which in the context of historical mistreatment and government unresponsiveness, requires an inordinate amount of time to address. Many of these issues are common to all Aboriginal communities across Canada, while others are specific to First Nations, or to impacted local tribal councils or treaty organizations, and each Aboriginal community has specific concerns. The ongoing dynamic with the federal government, as well as the recent history of materially advancing and expanding Aboriginal interests only through judicial challenge after decades of frustratingly slow negotiation, gives context to the political agenda of Aboriginal governments. With a mandatory two-year election cycle, most Aboriginal governments struggle politically to effectively implement change and advance the more critical health, social, and sustainability agendas of their communities, and entering into commercial relationships, regardless of their apparent long-term benefit to the community, can be a challenge.

Those Aboriginal communities who are more sophisticated, or who have experienced more commercial or economic success, often are able to separate the political elements from the business administration functions, and have incorporated economic development arms in order to maintain political independence and promote commercial integrity. For the majority of Aboriginal communities across Canada, however, sitting Chief and Council, together with their third party advisors, de facto fulfill the business development function concurrent with their executive function. As a consequence of past bad faith transactions with industry and internal transparency issues, there can be significant and vocal distrust for commercial proposals, both among Chief and Council and the community at large, and a demonstrated reluctance to commit to a project or partner without significant consensus building efforts. This lack of trust and community wide consensus building necessitates repetitive presentations to the entire community using visual aids and storytelling in order to communicate who the proponent is, the nature of the project being proposed, and how the affected Aboriginal community can be expected to benefit from the energy development. The manner in which the nature and structure of a proposed commercial relationship, particularly the more complex ones, is presented to Chief and Council, and the community becomes as important as the technical merits and profitability of the energy development itself. 
While the law is clear that Aboriginal community leadership has the legal capacity to contract on behalf of its membership, ${ }^{74}$ the practical realities of structuring and maintaining a sustained commercial relationship with an affected Aboriginal community are markedly different than what can be anticipated with a commercial corporate entity. The key to avoiding the uncertainties associated with election cycles, specific elected representatives, and contractual enforcement is to align the interests of the energy developer with what the tribal elders and the broader community view as the long-term needs of the affected Aboriginal community. In particular, if an energy developer can successfully engage and build consensus with the tribal elders and the broader community, the tribal elders can play a significant role in ensuring contractual compliance and the ultimate success of the energy development notwithstanding the notoriously disruptive short election cycles and lack of separation between elected officials and the business administration function, and transparency issues with individual elected officials.

In our experience, Aboriginal communities (and in particular, the tribal elders that influence traditional decision making) are not opposed to energy development, only to energy development in respect of which they do not equitably participate, or that is irresponsible in scope or implementation. Traditional Aboriginal governance models encourage leaders of today to base their decisions on whether they would benefit their children seven generations into the future, including embracing energy development provided it is conducted in a sustainable manner with demonstrable benefit being returned to the community. In practical terms, a commercial relationship which aligns with the longterm interests of a communal society will be honoured and enforced by the community itself through its elders and membership. By convincing the elders and the community at large that the commercial arrangement aligns with the long-term interests of the community, the elders and the broader community will facilitate compliance with the spirit of the agreement without regard to the leadership from time to time.

\section{Structuring The Aboriginal Commercial InTEREST}

Notwithstanding the lack of an external domestic law requirement, a number of affected Aboriginal communities have found innovative ways to participate in and take advantage of energy development opportunities on their traditional lands. These communities are involved in employment, procurement, training, community infrastructure, revenue sharing, comanagement, joint ventures, and other forms of economic participation. Commercial relationships providing affected Aboriginal communities with meaningful economic participation in energy developments on their traditional lands utilize a combination of three general categories of benefit: (1) a share of the passive resource revenues generated by the energy development either as a royalty share of the energy developers commercial interest, or as a share of the Crown tenure bonus payment, resource production royalties, and periodic rental payments; (2) contractual preferences for training and employment opportunities for community members, and procurement opportunities for community and member-owned businesses; and (3) a direct equity participation or active working interest in the energy development itself. 
As an Aboriginal government, creating fiscal certainty without putting the current or future assets of the community at risk is often a priority for the leadership of the affected Aboriginal community. This risk-free fiscal certainty can be achieved through passive resource revenues and therefore it is often one of the first requests made by an affected Aboriginal community when an energy developer initiates its consultation process. ${ }^{75}$ The Aboriginal government is also often under political pressure to secure contractual preferences for employment and business opportunities, as these translate into immediate benefits for individual members and member-owned businesses.

While elements of these two categories of revenue may invariably need to be included in packaging the commercial interest, in our view, neither represent true informed consent but rather an opportunistic acquiescence on the part of the affected Aboriginal community. It is important to make a clear distinction between commercial arrangements that provide these passive resource revenues and contractual preferences to the affected Aboriginal community carved out of the energy developer's commercial interest, and commercial arrangements that provide an active equity participation interest in the energy development itself. The former provides little in the way of capacity building for the Aboriginal community, does not invite input by the community into the nature, extent, and pace of energy development, does not deliver any great understanding or insight into the energy development itself, and in our view, does not fully meet the needs of alignment and informed consent. ${ }^{76}$

Providing an active equity participation interest to affected Aboriginal communities is a key element in obtaining informed consent and in reaching the degree of alignment necessary for the permitting of energy developments to proceed on predictable timelines, and for the requisite social license from those communities for operations to be conducted over the longterm without disruption. Equity participation provides affected Aboriginal communities with a voice in decision-making, aligns their interests with those of the energy developer, increases self-reliance by providing a line of sight to meaningful wealth creation and financial sovereignty, and ensures that both parties share in the costs, benefits and risks of energy development activities on traditional lands. The potentially meaningful wealth creation associated with equity participation provides the affected Aboriginal community with an avenue for financial sovereignty as these own-source revenues are outside of federal government control and are available for discretionary use at the community level to improve housing, provide social services, and stimulate their local economy.

\section{Structuring Aboriginal Equity Participation}

The benefits of active equity participation to affected Aboriginal communities are manifold in that they become directly involved in the conduct of the business, receive part of the profits from the energy development activities, and position themselves to significantly increase self-reliance and build long-term capacity. The typical process for structuring an commercial production is a common ask in the context of oil sands development in Alberta.

A passive interest is equivalent to a non-convertible gross overriding royalty (being an interest that aligns the top line in that more production is better), while an equity or working interest participation seeks alignment on the bottom line, bringing with it an understanding and appreciation by the community of the cost of capital, commodity prices, product transportation constraints, macro-economic trends, and the impact of delays and cost burdens. 
Aboriginal equity participation interest involves a determination of: (1) the level of project participation; (2) the allocation of the determined equity participation interest among multiple affected Aboriginal communities, if applicable; (3) the determination of the appropriate joint venture structure and governances; (4) the determination of appropriate restrictions on alienation and exit mechanisms; and (5) securing capital providers to fund the affected Aboriginal community's share of costs and expenses.

In discussing co-owned assets and business entities, it is important to distinguish between four key concepts: ownership, operatorship, revenues, and expenses. Shared ownership of the entity or asset must be distinguished from control or operatorship of the entity or asset, and overall ownership must be also be distinguished from varying responsibilities for the costs and expenses associated with the entity or asset, and similarly, from the varying entitlement to the benefits or distributions generated by that entity or asset as a consequence of the varying participation in costs and expenses.

In our experience, the offered range of Aboriginal equity participation interests has a lower limit of 5 percent, in order to be meaningful, and an upper limit of 50 percent. Subject to our discussion below regarding the meaning and impact of operational control and operatorship, so long as the joint venture documentation delegates sufficient authority to the operator to progress the development and includes the right of participating parties to differentially recover an appropriate preferred return on amounts funded on behalf of nonparticipating parties, the ownership percentages do not necessarily reflect the actual financial returns from the project. Consideration may also be given to whether homogeneous interests are required throughout the development, or whether it can be segmented based on functionality, or risk and return profiles. By way of example, upstream can be separated from midstream, processing can be separated from transportation within midstream, and the surface lease or right-of-way can be separated from the facility or pipeline, and the physical facility or pipeline can be separated from the right to utilize the capacity itself.

While the allocation of project ownership between the developer and the affected Aboriginal communities may be viewed as adversarial, there is a natural alignment and mutual benefit in consummating the commercial relationship that facilitates resolution and reaching a consensus. In our view, the far more difficult and unconstrained problem that presents itself is determining a mechanism for equitably allocating that participation interest among the affected Aboriginal communities. While ultimately up to the affected Aboriginal communities, it can be helpful for the developer to act as mediator in this determination. The simplest solution, of course, is to distribute the designated Aboriginal interest equally among the identified affected Aboriginal communities. This simplicity, however, fails to take into consideration and respect the differential impact that a development can have on the various affected Aboriginal communities. ${ }^{77}$ We also cannot overemphasize the challenge and complexity inherent in assembling larger Aboriginal consortiums that propose blending the

A proposed oil sands pipeline from Alberta to the British Columbia coast, for example, has at least three distinct categories of impact and risk: (1) those in proximity to the oil sands production; (2) those in proximity to the pipeline route; and (3)those in proximity to the marine loading facility and tanker traffic. Even those communities in proximity to the oil sands production can experience markedly different impacts reflecting physical proximity and the current or historical use of the affected traditional lands. 
interests of various cultural groups over great distances. As can be imagined, an Aboriginal consortium that combines the interests of peoples of Cree and Dene ancestry with those of coastal peoples as well as Métis peoples must be carefully considered, structured, and introduced, with particular care taken to devise an effective governance structure that is respectful of each culture. An overriding concern for both the energy developer and those Aboriginal communities in agreement, is the treatment of holdout communities and an understanding of what number represents an acceptable quorum or level of participation to proceed. Recognizing that each single community may present the equivalent unacceptable level of above ground risk, a sophisticated analysis is required. To the extent that the number of holdouts is manageable, those communities in agreement may devise a mechanism to hold the interests of any non-consenting communities in trust so that projects may proceed without unanimity.

In general terms, the co-ownership by an energy developer and one or more affected Aboriginal communities of an energy development asset takes one of two forms: a co-owned business entity such as a corporation or limited partnership, which business entity owns the asset, or the energy developer and the community, or a wholly-owned business entity of the community, have direct co-ownership of the asset. In the simplest example of a co-owned asset, each of the energy developer and the Aboriginal corporation own 50 percent of the asset, an operating committee with equal representation is formed, the developer acts as the initial operator of the asset, each owner is responsible for its ownership interest share of costs and expenses including operator compensation, and each party is entitled to its ownership interest share of revenue, subject to any recovery penalty assessed as a consequence of an owner failing to fund operations. Even in this simplistic example, a number of key negotiation points present themselves.

First, the scope, extent, and specific subject matter of the authority and discretion delegated to the operator by the operating committee, and the mechanism and criteria of becoming and replacing the entity serving as operator, require thoughtful drafting. The delegated scope of operator authority is almost entirely a function of the nature of the project and the level of its development and overarching guidelines are of little use. In general, the operator proposes annual programs and budgets, and to the extent they are approved, those programs and budgets are funded in accordance with ownership percentages, and implemented and executed by the operator with a discretionary cost variance without requiring re-approval. To address the circumstance where the proposed annual program and budget is not approved, a mechanism for independent or sole risk operations becomes necessary, as well as a determination of the penalty consequence associated with the failure to participate in and fund operations. Typically, a disproportionate share of revenue is returned to the participating owners until such time as they have recovered a risk adjusted share of the expended amounts.

With respect to operatorship, the entity best qualified to efficiently and optimally operate an asset should act as the operator of that asset, and in the ordinary course, that will initially be the proponent of the energy development (but depending on the nature of the asset could also arguably be a third party). Presumably, over time and depending on the success of efforts at capacity transfer to the Aboriginal community or company, the Aboriginal community or company may become sufficiently qualified to operate upon the exit of the 
initial operator, or perhaps earlier. The criteria for becoming, remaining, and removing the operator should be made clear as it is a singular position with considerable influence over the success of the joint venture and that cannot be shared. In circumstances where an operatorship challenge or replacement leads to a dispute, an arbitrated result based on clear criteria may be effective, or the pro tem appointment of a third party operator.

If a co-owned corporation or limited partnership structure is used, with the business entity owning the asset, the issues described above remain relevant except they are addressed in the limited partnership agreement or unanimous shareholders agreement instead of the joint venture or co-ownership agreement. Since the asset is now held 100 percent by the co-owned business entity, the operator role is initially filled by a third party operator, which in the ordinary course is the energy development proponent. Although the mechanics and tax consequences may differ, the business points remain the same, subject to what we view as two notable benefits of the co-owned entity structure. Capacity transfer in the context of a co-owned business entity may be easier as the stand-alone entity can be populated initially by employees of the proponent but subsequently by community members, which allows the co-owned entity to more easily develop the expertise and experience necessary to take over as operator. A co-owned entity may more easily facilitate the co-owner's intention to jointly access capital either from traditional capital providers, or from government sources as a consequence of the Aboriginal ownership participation. In the latter circumstance, care should be taken in structuring the co-owned entity to remain eligible as an "Aboriginal business" for any available government programs or funding.

Engaged participation at the operating committee level in the case of co-owned assets, or at the board of director level in the case of co-owned entities, is important as it ensures longterm alignment between the energy developer and the Aboriginal community leadership, and facilitates the capacity transfer to the community that will allow the community to develop other businesses. The recent experience that Canadian energy developers have patiently gained through joint ventures with sovereign wealth funds and foreign state owned enterprises can serve as a useful template for the capacity transfer. Arguably, both the Aboriginal community and the energy developer benefit from the capacity transfer initiatives, as the energy developer increases diversity objectives, awareness-building, potentially improves decision-making, strategic planning, and enhanced accountability to both the Aboriginal community, its own shareholders, and the investment community in general, which should lead to more successful projects.

To the extent that affected Aboriginal communities are offered an equity participation interest in an energy development in order to minimize long-term Aboriginal above ground risk, it follows that, in order for the energy developer to receive the value bargained for, the Aboriginal community must hold that equity interest for the life of the energy development. While there otherwise is considerable symmetry in the joint venture arrangement between the energy developer and the Aboriginal community from an ownership perspective, this inherent restriction on the community's ability to monetize its ownership position introduces a fundamental asymmetry to the relationship. As an energy development progresses through the various stages of discovery, exploration, development, and commercial production through to maturity, the size, character, and identity of the entity having control of that energy development will have to change. Whether by way of asset transfer, joint venture, or 
corporate change of control or reorganization, the non-Aboriginal equity component and operatorship of the energy development will almost certainly change to reflect the then required expertise, capacity, and capital. A tension can develop within the Aboriginal community if, during pre-production and prior to the receipt of material revenues, there is a perception that the energy developer has reaped a monetization windfall upon an exit. On the other hand, recognizing that many energy developments have inherent associated commodity price risk, from an Aboriginal government perspective, the inability to exit the energy development represents a significant restriction on its ability to manage its asset base and diversify its investment portfolio.

It should also be recognized that there are other energy development assets which may represent strategic, long-term investments for the Aboriginal community and which the community may wish to eventually seek to own 100 percent of, such as electricity generation and transmission facilities, or on-reserve commercial developments. For these categories of strategic assets, the Aboriginal community may seek a right of first refusal, or a fair market value option, that allows the community to exercise a degree of control over who its partner is by acquiring the non-Aboriginal equity interest in the energy development. It must be recognized by the energy developer that, to the extent that an affected Aboriginal community provides its informed consent to an energy development proceeding by entering into a commercial arrangement, the grant of that informed consent is based, at least in part, on the technical and operational expertise and capabilities, and perhaps environmental and sustainability record, of the proponent entity. It follows that it may not be unreasonable for affected Aboriginal communities to expect assurances in respect of the identity of its partners, and particularly the entity fulfilling the operatorship role.

Given the scale of most energy developments, securing an outside source of capital for the Aboriginal community is usually the most difficult step as most communities do not have the financial means to acquire the equity participation interest directly, and if acquired, do not have the financial means to fund the capital commitments associated with the equity participation interest. As with any energy developer, the non-public market sources of capital available to fund the equity participation interest of an Aboriginal community are broadly bank debt, mezzanine financing, and private equity funding. Aboriginal communities, however, have a difficult time accessing willing capital as the suite of providers prepared to engage in Aboriginal transactions is not well populated. That willingness to engage increases, and the cost of the capital provided is reduced, in cases where there are long-term, firm contracts with a pipeline or facility to provide assurance that loans will be repaid or preferred equity will be returned from the Aboriginal community's share of energy development revenue. Following the repayment of the capital provider's principal and investment return, the balance of the community's share of revenue from its equity participation interest is returned to the affected Aboriginal community as a shareholder or owner. Depending on the negotiated restrictions on alienation and exit mechanisms, the community can also see appreciable wealth creation upon a monetization of its equity participation interest in the energy development. In the future, if Canada hopes to obtain greater Aboriginal support for energy developments, it may adopt a broader approach to addressing Aboriginal interests and economic development. Rather than simply focussing on strictly fulfilling its legal obligation in respect of the duty to consult Canada may actively incent widespread equity participation, including providing Aboriginal communities with 
increased access to capital, loan guarantees, and providing tax incentives for energy developers.

In this regard, a special study on the involvement of affected Aboriginal communities in economic development activities in Canada by the Standing Senate Committee on Aboriginal Peoples acknowledges that governments have an important role to play in facilitating commercial relationships between industry and Aboriginal communities and recommended that the federal government take a lead role in facilitating partnerships between Aboriginal peoples and industry, including implementing tax incentives to encourage such partnerships. ${ }^{78}$ Similarly, in his report to the Prime Minister, Canada's special federal representative on west coast energy infrastructure concluded that, as Aboriginal communities face barriers in accessing financing to participate in large scale energy developments, there is a role for governments to provide loan guarantees or other financing measures to enable Aboriginal communities to become equity owners in major projects. Loan guarantees would provide Aboriginal groups with security that would enable them to borrow at lower than commercial interest rates, thereby making potential investments more feasible and profitable. Under this approach, governments would serve as a financial backstop should the borrower be unable to repay the loan. ${ }^{79}$

\section{Concluding Thoughts}

This article has attempted to describe how energy development in Canada is inextricably linked to the rights, expectations, and aspirations of Canada's Aboriginal peoples and how developments on the international stage are influencing and shaping this relationship. In particular, the broad acceptance of the UN Declaration seems to be both raising Indigenous expectations and hastening the implementation of those international norms. Given the apparent dissatisfaction of Aboriginal peoples with the current approach in Canada, it appears that unless real change is advanced politically and practically, energy developers will continue to face considerable above ground risk as they attempt to pursue development.

This article has also sought to provide a perspective on the business principles and practices being embraced by progressive companies internationally, including through the UN Compact, the UN Principles, the UN Business Guide and the shared value framework. In our experience, Aboriginal communities are not necessarily opposed to energy development, only to energy development in respect of which they do not equitably participate, or that is irresponsible in scope or implementation. It follows that energy developers who seek to undertake activities on traditional lands in Canada may be able to obtain informed consent and proceed in a timely manner by structuring commercial arrangements that align with the interests of the impacted Aboriginal communities and create meaningful participation. As these emerging practices become mainstream within the energy industry, we believe that further reconciliation of Aboriginal interests with mainstream society will result.

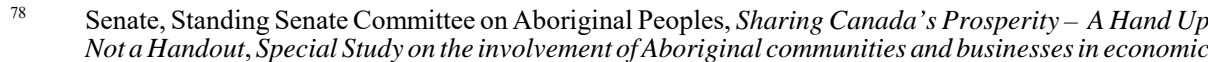
development activities in Canada (March 2007) (Chair: Gerry St Germain), online: Parliament of Canada <www.parl.gc.ca/Content/SEN/Committee/391/abor/rep/rep06-e.pdf>.

79 Natural Resources Canada, Forging Partnerships, Building Relationships: Aboriginal Canadians and Energy Development, by Douglas R Eyford, Catalogue No M4-109/2013E(Ottawa: NRC, 2013), online: $<$ https://www.nrcan.gc.ca/sites/www.nrcan.gc.ca/files/www/pdf/publications/ForgPart-Online-e.pdf $>$. 
this page is blank - do not strip it in 